\title{
Effects of the Core Functions of Government on the Diversity of Executive Agendas
}

\author{
*Will Jennings, ESRC Research Fellow, School of Social Sciences, University of \\ Manchester, Oxford Road, Manchester M13 9PL, United Kingdom \\ (will.jennings@manchester.ac.uk).
}

*Shaun Bevan, Research Associate, School of Social Sciences, University of Manchester, Oxford Road, Manchester M13 9PL, United Kingdom

(shaun.bevan@manchester.ac.uk).

*Arco Timmermans, Research Director, Montesquieu Institute, Lange Voorhout 86 - 32, 2514 EJ, Den Haag, the Netherlands and Associate Professor, Department of Public Administration, Leiden University, and (ATimmermans@,fsw.leidenuniv.nl).

Gerard Breeman, Assistant Professor, Department of Public Administration, Wageningen University, the Netherlands.

Sylvain Brouard, Senior Research Fellow FNSP, SPIRIT, Sciences Po Bordeaux, Univerity of Bordeaux, France.

Laura Chaques, Associate Professor, Department of Political Science, University of Barcelona, Spain.

Christoffer Green-Pedersen, Professor, Department of Political Science, University of Aarhus, Denmark.

Peter John, Hallsworth Chair of Governance, School of Social Sciences, University of Manchester, United Kingdom.

Peter B. Mortensen, Assistant Professor, Department of Political Science, University of Aarhus, Denmark.

Anna Palau, Postdoctoral Research Fellow, Department of Political Science, University of Barcelona, Spain.

${ }^{*}$ Corresponding authors

Acknowledgements: Will Jennings and Shaun Bevan thanks the UK Economic and Social Research Council for support of the research project Legislative Policy Agendas in the UK (R105938), part of a European collaboration funded by the European Science Foundation (ESF): a EUROCORES ECRP 2007 project, The Politics of Attention: West European Politics in Times of Change, led by Stefaan Walgrave, Department of Political Science, University of Antwerp. Arco Timmermans thanks the Department of Internal Affairs and the Environmental Assessment Agency in the Netherlands for their financial support. Work on this research was facilitated by the Montesquieu Institute in The Hague. We also thank the US Policy Agendas Project for providing the dataset on State of the Union Addresses of the President. Thanks to Christian Breunig, David Lowery and other participants at the Annual Meeting of the Comparative Agendas Project in The Hague, June 2009. 


\begin{abstract}
The distribution of attention across issues is of fundamental importance to the political agenda and outputs of governments. This paper presents an issuebased theory of the diversity of governing agendas where the core functions of government - defence, international affairs, the economy, government operations and the rule of law - are prioritized ahead of all other issues. It undertakes comparative analysis of issue diversity of the executive agenda of several European countries and the United States over the post-war period. The analysis uses a new dataset of annual executive speeches which consists of 50,000 policy statements between 1945 and 2008. The results offer strong evidence of the limiting effect of core issues - the economy, government operations, defence and international affairs - on agenda diversity. This suggests that not only do some issues receive more attention than others, but also that some issues are only attended to at times when the agenda is more diverse. When core functions of government are high on the agenda, executives pursue a less diverse agenda focusing the majority of their attention on fewer issues. Some issues are more equal than others in executive agenda-setting.
\end{abstract}


"In an information-rich world, the wealth of information means a dearth of something else: a scarcity of whatever it is that information consumes. What information consumes is rather obvious: it consumes the attention of its recipients. Hence a wealth of information creates a poverty of attention" (Simon 1971, pp.40-41).

At any moment in time, policy-makers in political systems of all shapes and sizes are confronted with an abundance of information about the state of the world (Simon 1971; Jones and Baumgartner 2005). Such information relates to matters ranging from domestic policy to international affairs - on topics such as the economy, education, immigration, public services, defence, crime and climate change. This never-ending flow of information requires processing, prioritization and action as policy-makers attempt to incorporate information into their decisions. From time to time, certain issues have far-reaching effects for the structure of attention across the entire political agenda. For example, the events of 9/11 led to a rapid elevation of the issue of national security in the US at the expense of other policy concerns, such as the environment and civil liberties. Likewise, the events of the Credit Crunch shifted the focus of the agenda away from issues such as healthcare, the environment and immigration in European countries.

The distribution of attention across issues is of fundamental importance to the political agenda and outputs of governments. How do policy-makers distribute their finite attention across or within issues? Every policy choice has potential consequences for diversity of the agenda as a whole: such choices may squeeze out attention to other issues or precipitate changes to policies in related domains. Studies of public policy generally consider individual issues or domains 
independent from each other (e.g. Downs 1972; Kingdon 1984; Baumgartner and Jones 1993) even though trade-offs and conditions are known to be required for policy change (e.g. True et al. 2007). Yet, in practice policy decisions are bounded (Simon 1957), resources are limited (Jones and Baumgartner 2005) and decisions are interdependent of one another (True et al. 2007). The diversity of the agenda indicates the degree to which different issues are the focus of political attention. Some issues gain access to the agenda, while others do not. This determines the amount of information involved in decision-making. But certain information can be privileged above other information. The diversity of the agenda may be more sensitive to attention to some issues compared with others. This raises questions about the relationship between agenda diversity and attention to issues. Is this an asymmetric relationship where some issues are more equal than others? Some issues can dominate the agenda, while other issues gain access only when the main concerns of government are less urgent.

The operation of government involves real-time processing of information about the state of the world. Governing agendas matter because they are an indicator of priorities that are not confined to election time or to an institutional calendar. This is a common feature across all democratic systems. Comparative analyses of political attention are relevant to questions regarding the comparative design of political systems and responsiveness of institutions. There is a longstanding tradition of comparative scholarship concerning the effect of institutions on political processes and outcomes (Lijphart 1994; 1999; Cox 1997; Powell 2000; Strøm 2000; 2003; Soroka and Wlezien 2010). Systematic comparative analysis of government agenda-setting is disparate in comparison to that concerning issue competition by parties during election periods (e.g. Budge 
and Hofferbert 1990; Klingemann et al.1994; Petrocik 1996; Budge et al. 2001;

MacDonald and Budge 2005; Grossback et al. 2006). Some recent studies explore dynamic properties of executive agendas within single countries (e.g. GreenPedersen 2007; Breeman et al. 2009; Jennings and John 2009). Not much is known about the diversity of government agendas. That is, the spread of attention across issues. Comparative analysis can be concerned both with the differences and similarities of the structure of political attention (Baumgartner et al. 2009; Brouard et al. 2009; Jones et al. 2009a).

This paper focuses on issue diversity and undertakes a comparative analysis of the executive agenda of several European countries and the United States over the post-war period. The organization of the paper is as follows. First it explains why the structure of issue diversity in political attention is important for understanding agenda-setting processes. Second, it presents an issue-based theory of the diversity of governing agendas. This generates a hypothesis of the effect of specific issues on diversity, controlling for the autoregressive nature of agendas over time. To test this hypothesis, time series cross-sectional analyses of issue diversity of the executive agenda in six countries are undertaken. These countries are the parliamentary systems of Denmark, the Netherlands, Spain and the U.K., the semi-presidential system of France and the presidential system of the U.S. It estimates Shannon's H - a measure of information entropy - to model issue diversity of executive agendas over time.

\section{Issue Diversity of Government Agendas}

The concept of agenda diversity (McCombs and Jian-Hua 1995; Jochen and De Vreese 2003) provides insight into the dispersion of attention of government to issues across the political agenda. This describes how government 
shares its attention between various issues competing for the finite space available on the agenda. A diverse agenda is one in which attention is shared between a broad range of issues, whereas a less diverse agenda is one in which attention is confined to only a few issues. However, diversity does not just refer to the total number of issues on the agenda, but rather refers to the concentration of the agenda across issues. In other words, the amount of attention assigned to each issue affects diversity as well as the total number of issues on the agenda. Since the seminal work of Schattschneider (1960), politics has been understood as the mobilization of support or opposition to issues, and the competition for attention to particular issues over others. The concept of agenda diversity therefore relates to how much attention is assigned to each issue, but also to how much attention is assigned across all issues.

\section{The Structure of Issue Diversity in Political Attention}

The attention-driven model of policy choice developed by Jones (2001) argues it is attention, rather than resources, which is scarce for decision-makers in this world of information abundance. While governments and their bureaucratic apparatus are institutionally designed to attend to many issues simultaneously, they must prioritize the issues that are most urgent and important to them, and do so on the basis of a limited set of indicators. There are institutional and other costs associated with retrieval and processing of information. Political systems provide mechanisms for parallel processing of hundreds of issues, such as bureaucracies, coalition negotiations and legislative hearings (e.g. Jones 1994; Timmermans 2006; True et al. 2007; Müller and Strøm 2008). Fewer issues are processed serially at the higher reaches of government by actors such as the president or prime minister, the legislature and the supreme or high court. Policy- 
makers have a finite amount of time and resources to consider available information, leading to bounded decision-making (Simon 1971). This is a feature of all political systems.

The distribution of policy-making resources across different jurisdictions is designed to enable the simultaneous handling of multiple issues, where the longrun stability of the agenda is maintained through the incremental adjustment of attention and policies. This equilibrium state undergoes sudden change when certain issues are elevated into the realm of macro-politics, while attention to other issues is downgraded. This generates an iterative process of updating where decision-making follows an autoregressive process for extended periods of time, but is subject to episodic corrections and over-corrections. Policy-makers may overweight certain indicators at the expense of others, and from time to time information signals exceed the threshold of attention that is required to stimulate a response. This is consistent with theories of agenda cycling (e.g. Shepsle and Weingast 1984; Riker 1986), where past agenda choices influence subsequent outcomes, and theories of path dependence (e.g. North 1990; Pierson 2000). For comparative political analysis, the common structure of governing agendas is important for understanding similarities in government decision-making across countries (e.g. Baumgartner et al. 2009; Jones et al. 2009a). This differs from the study of partisan effects on policy programmes (e.g. Budge and Hofferbert 1990; Klingemann et al.1994; Budge et al. 2001; MacDonald and Budge 2005), since while the content of governing agendas may change due to partisan preferences (mediated by electoral outcomes) its distribution is shaped by the overall spread of issues confronting government. While political parties may engage in attentionshifting and selective emphasis (Budge and Fairlie 1983; Petrocik 1996), e.g. left 
parties tend to pursue social programmes whereas right parties focus on immigration, this does not necessarily alter the general distribution of attention.

The attention-driven model of policy choice suggests that the day-to-day business of government exhibits an incremental model of issue dynamics, subject to occasional shocks. ${ }^{1}$ Because attention is finite agenda diversity should maintain a long-run equilibrium, regardless of the degree of low (incremental) or high (punctuated) change observed for individual topics. While there might be shortrun punctuations in attention (Baumgartner and Jones 1993), the overall diversity of the agenda remains stable as it absorbs sudden changes. Just as some issues are quickly elevated in importance, others are downgraded to the fringes of government attention. The institutional capacity of government for serialprocessing of information is limited, also constraining the diversity of the agenda. In addition, decision-makers weight information according to its importance, generating a disproportionate pattern of attention (Jones and Baumgartner 2005). Together, finite agenda capacity and the weighting of information restrict the diversity of the agenda.

This literature on agenda-setting and decision-making suggests that the issue diversity of government attention is a function of its past structure subject to random errors, persisting in a long-run equilibrium. This autoregressive process suggests that subsequent steps are random in direction but tend back towards the long-run equilibrium of the political system. While diversity of governing agendas might be subject to erratic patterns and fluctuations in the short-run, these should return to their long-run state. Despite punctuations in attention of government to specific topics, issue diversity tends to revert to its long-run equilibrium. 
The Effect of the Primary Functions of Government on Agenda Diversity $\left(H_{1}\right)$

When considering the agenda of national government the key function of the state is an important explanation of diversity of attention. Kingdon's (1984) agenda-setting theory argues that a combination of policies, problems and politics determines which issues receive the attention of government and which issues are unattended to. Other studies of agenda-setting (e.g. Cohen 1963; Downs 1972; McCombs and Shaw 1972; Baumgartner and Jones 1993) also suggest that certain conditions must be in place for an issue to access the agenda. Such analyses tend to consider the characteristics associated with decision-making on individual issues or domains independent from one another. That is even though it decisionmaking is bounded (Simon 1957), resources are finite (Jones and Baumgartner 2005) and decisions are interdependent (True et al. 2007). Furthermore, some issues are more critical to government than others. Such concerns can be traced to classic theories of the state such as Hobbes (1651), Locke (1689) and Rousseau (1762): where the state's core responsibilities are to defend its borders, manage its relations with foreign powers, provide for the general well-being of its people and maintain the apparatus of government. Similar ideas are to be found in the work of Wilson (1889), where the constituent (or primary) functions of government were again consistent with the importance of preservation of the state, defence of the realm, promotion of the common good, maintenance of the rule of law and management of relations with foreign powers. Public policy theories appear to assume that the essential functions of government exist but do not affect decisionmaking in other domains. Even ideas such as simultaneous policy streams (Kingdon 1984) and parallel-processing (Jones and Baumgartner 2005; True et al. 2007) do not test the interdependent structure of political attention. While the size 
and functions of government have increased since the time of such classic theories of state, these central functions of national government remain the main focus of its agenda. Across most political systems, government agendas tend to focus heavily upon the economy, defence and international affairs (e.g. Cohen 1995; Edwards and Barrett 2000). Such ideas have implications for the mobilization of bias (Schattschneider 1960), determining which issues government attends to and which issues it ignores. Given the finite nature of attention, information processing is not equal across all issues. The relationship between information and government attention may well be asymmetric.

Drawing upon the classic theories of state and the idea of issue intrusion (Jones and Baumgartner 2005), it is possible to hypothesize that there are systematic effects on agenda diversity associated with changes in the level of attention to specific issues. Core concerns of the state such as defence and the economy should be associated both with a high level of government attention and with a less diverse agenda. Other subjects of political attention might be either conditional or peripheral, gaining access to a more diverse agenda when the essential concerns of state are less salient. These issues can be described as selective issues consistent with theories of selective emphasis from the study of political competition (Budge and Farlie 1983; Budge et al. 2001). Government can decide whether or not to attend to selective issues, in contrast to those issues related to its core functions. Changes in attention to such issues are not expected to alter the overall structure of the government's agenda in the same way as the core functions of government. For example, punctuations in attention to a selective issue such as immigration might reflect change within a particular domain, but not lead to a fundamental reorganisation of attention which remains 
largely focused on the core issues. In contrast, war or other such fundamental shocks are expected to lead government to restructure its attention, giving lower priority to or even dropping issues that it had dealt with selectively. This interpretation of agenda diversity integrates the importance of informationprocessing in the attention-driven model with classic theories of the state: where the core functions of government - defence, international affairs, the economy, government operations and the rule of law - are prioritized ahead of all other issues. Other information on selective issues is incorporated into decision-making when executive concern with core issues wanes. This has fundamental implications for understanding the nature of issue dynamics, since it identifies the conditions under which certain issues are elevated to the realm of macro-politics and receive attention from government.

According to this model, effects of government attention to core issues on agenda diversity will be negative. As the executive agenda assigns more attention to the core functions of government, which already constitute a large share of the governing agenda, there is a reduction in the overall level of agenda diversity. This generates the hypothesis: overall issue diversity of the national government agenda is subject to effects of the level of attention to core issues.

$\mathrm{H}_{1}$ : Increases in attention of government to core issues - the economy, international affairs, defence, government operations and law and order leads to a lower diversity of the agenda.

\section{Executive Speeches in Six Countries}

The national government agendas considered in this paper are the annual statements of policy priorities and commitments presented in executive speeches 
in a number of countries. In many political systems the head of state or head of government delivers an annual formal statement, on behalf of the executive, setting out its policy priorities for the year ahead. These speeches are forwardlooking statements, communicating general priorities and specific measures that the executive intends to address in the following year. While in some countries, such as the US, this indicates a governing agenda that is independent of the legislature, it nevertheless expresses the policy intentions of the executive in the same way as speeches in parliamentary systems, such as in the Netherlands. This substantive function of executive speeches is reflected in their effect on policy outcomes (e.g. Bara 2005). Such a convention is found in both presidential and parliamentary systems, and performs the political function of highlighting matters of importance and detailing the legislative programme that government intends to enact in the forthcoming year. This analysis considers the issue diversity of such executive agendas in six countries. Four of these are parliamentary democracies: Denmark, the Netherlands, Spain and the UK; one is a semi-presidential system: France; and one is a presidential system: the US. Of these, the U.K. and U.S. are two-party systems while Denmark, France, the Netherlands and Spain are multiparty systems. Coalition governments are the norm in Denmark and the Netherlands, often with minority status in Denmark where governments depend on opposition cooperation in policy-making. The design of comparative analysis is neither a most-similar nor a most-different systems approach but considers a mixed bundle of cases for testing hypotheses about the sources of issue diversity of executive agendas.

In each of the countries, the annual speech provides a high-profile signal of the priorities of the executive to the legislature, governing and opposition parties, 
bureaucrats, interest groups, the media and the public. This occurs at the beginning of the parliamentary session in Denmark, the Netherlands and the UK, and around the start of the calendar year in France and the U.S., while in Spain the timing of the speech is at the discretion of the government. The speech is made on behalf of the government by the prime minister in Denmark and Spain, the president in France and the US, and the monarch in the Netherlands and UK In each case it summarizes issues or policies that are of interest to executive government, including its legislative and executive priorities for the forthcoming year (e.g. Cohen 1995; 1997; Hobolt and Klemmensen 2005; 2008; Breeman et al. 2009; Green-Pedersen et al. 2009; Jennings and John 2009). The speech sometimes contains ceremonial and symbolic statements about the government's achievements and major domestic or international events. Despite some crossnational variation in institutional format, the speech is almost invariably substantive and performs a comparable function of agenda-setting and attention signaling for the executive in each political system. This is reflected in similar effects upon policy outcomes (e.g. Bara 2005) and in responsiveness to the same inputs such as public opinion (Cohen 1997; Hobolt and Klemmensen 2005; 2008; Jennings and John 2009; Jones et al. 2009b). These executive speeches therefore constitute a common form of government agenda that is suitable for comparative analysis. Further, such speeches represent a meaningful and reliable measure of executive attention across each of the six countries. By highlighting certain policy issues and ignoring others, the government sets and shapes the national agenda for the coming year.

\section{Data \& Analyses}


This analysis uses a dataset on annual executive speeches that consists of approximately 50,000 coded policy statements. The full text of the annual speech of the executive was collected for Denmark (1953-2006), the Netherlands (19452007), Spain (1982-2007), the U.K. (1945-2008), France (1958-2006) and the U.S. (1946-2005). The text of each speech was coded using sentences or quasisentences as the unit of analysis. ${ }^{2}$ The transcripts were coded according to the policy content coding system of the Comparative Policy Agendas Project, adapted from the original U.S. Policy Agendas Project (see Baumgartner et al. 1998; www.policyagendas.org). This coding framework contains nineteen major topics such as macroeconomics, health and international affairs. These topic codes are reported in Table 1. The national versions of the codebook adhere to the full range of major topic codes, ensuring that the datasets are comparable across countries. This generates data on both the frequency and proportion of executive statements for all countries in a given year on each of the major topics.

[insert Table 1 about here]

\section{Entropy as a Measure of Agenda Diversity}

To measure the issue diversity of attention of government across the entire agenda, entropy scores are calculated for the content of executive speeches according to major topic codes. The measure of entropy used here, Shannon's H (1948), is adapted from information theory to estimate the issue diversity of policy-making attention (Jones and Baumgartner 2005). ${ }^{3}$ Shannon's H is a probabilistic measure of the spread of objects or observations across a defined number of (discrete) nominal categories. This is represented as the logarithm of 
the sum of probabilities of the different possible states in a system. The agenda has a low degree of entropy if executive attention is concentrated upon a single topic and a high degree of entropy if attention is widely dispersed over the agenda with all issues obtaining equal but limited coverage. Entropy therefore provides a measure of issue diversity of the political agenda. This measure of information diversity is represented in the form:

$$
\mathrm{H}=(-1) \sum_{i=1}^{n} \mathrm{p}\left(\mathrm{x}_{\mathrm{i}}\right) \ln \left(\mathrm{p}\left(\mathrm{x}_{\mathrm{i}}\right)\right)
$$

where entropy scores $(\mathrm{H})$ are estimated as the negative sum for all topics of the likelihood, $\mathrm{p}(\mathrm{x})$, that an object $x$ (in this instance a policy statement in the executive's speech) falls within a particular topic $i$, multiplied by the natural log of that likelihood. Since logs of zero cannot be calculated, it is assumed that $0 \times \ln (0)$ $=0$ for topics where there were no policy statements in a given year.

To demonstrate how this measure of agenda diversity works, consider the examples presented in Table 2. Example 1 shows a hypothetical agenda with just one issue receiving $100 \%$ of the attention, where the lowest possible entropy score (0) is therefore calculated. Example 6 shows an agenda where each issue receives an equal share of attention $(\approx 14.3 \%)$ and the highest possible entropy score for a seven issue agenda (1.95) is obtained. Examples 3 and 4 illustrate how a reversal in attention between Topic A and Topic B, with no other changes in attention to Topics C, D, E, F and G, does not change the overall entropy of the agenda (1.442). It is therefore possible for there to be a shift in attention between issues without a corresponding change in agenda diversity. Example 2 shows, in contrast, that if Topic A instead takes attention from all minor issues C, D, E, F and $\mathrm{G}$, there is a decrease in agenda diversity compared to Example 3. Example 5 
shows that a transfer of $25 \%$ of attention from the issue with the highest share in Examples 3 and 4 across other issues results in a more diverse agenda (1.844).

[insert Table 2 about here]

\section{Summary Statistics}

Prior to analysis of the diversity of executive agendas, summary statistics are reported for the total number of executive statements in the six countries. The mean number of statements is (in descending order) 280 in Spain, 268 in the U.S., 235 in Denmark, 126 in the Netherlands, 72 in the U.K., and just 42 in France. ${ }^{4}$ This reveals a degree of cross-national variation in size of the executive agendas across the executive speeches. ${ }^{5}$ The annual number of statements is plotted over time in Figure 1. This reveals some upward drift in executive agenda size in Denmark, the Netherlands, the U.K., and France. This upward drift is not replicated in the U.S. State of the Union Address (though there are punctuations in 1946 and 1981) or in the prime minister's speech in Spain (which is a shorter time series in comparison to the others). This suggests that both the format and the agenda-setting function of the executive speech is quite stable over time both within and across the six countries. There may be practical limits to growth in size of executive speeches.

The frequencies of mentions for each major topic are used as the independent variables in time series cross-sectional analyses by topic to test our hypothesis, $\mathrm{H}_{1}$. To consider differences in agenda diversity due to partisan control of government, the analyses include a variable to differentiate periods of left- and right-wing government. The effect of agenda size, measured by the annual 
number of statements, on issue diversity of executive speeches is controlled for in these tests.

[insert Figure 1 about here]

The content of the executive speeches is used to calculate entropy, the measure of agenda diversity for this analysis and dependent variable for testing the hypotheses. The entropy scores for each of the executive agendas, calculated by country * year, are plotted against the annual number of statements in Figure 1. The maximum possible entropy score for the nineteen major topic codes is equal to the natural $\log$ of 19 (i.e. 2.944). An entropy score of 0 indicates that attention is concentrated on a single topic, while a score of 2.944 indicates that attention is equally spread across all nineteen major topics such that each issue receives approximately $5.26 \%$ of the attention. From visual inspection of Figure 1 it appears that agenda diversity is mean-reverting over time within each of the countries, returning to its average level after short-term deviations.

The statistics reported in Table 3 indicate that there are differences in the mean level of agenda diversity by country. This appears to be lower in presidential systems than in parliamentary systems. The entropy score for the executive speech in semi-presidential France (1.797) is considerably less than for the four parliamentary democracies in Denmark (2.313), the Netherlands (2.456), Spain (2.166) and the UK (2.391), while the score for the presidential system in the US (2.116) is a fraction lower than the other countries. While this difference could result from institutional features such as the constitutional format and 
political function of each of the executive speeches, general inferences from this finding should be treated with caution.

As noted earlier, the agenda diversity of each of the executive speeches is mean-reverting over time (see Figure 1). This measure of agenda diversity is the dependent variable in the following analysis, using tests for unit root and time series cross-sectional analyses. It is because of this common structure of governing agendas, explained below, that differences between countries can be modelled with fixed effects in a time series cross-sectional format.

[insert Table 3 about here]

Cross-National Stability in the Structure of Political Attention - Diagnostics for Pooling of Countries for Comparative Analysis

In order to conduct analysis of similarities in the structure of governing agendas across these six countries, it is first necessary to establish that they exhibit the same underlying processes. For such a comparative design to be valid, differences of agenda diversity between countries must be confined to the mean level of diversity - reflecting institutional variation - with similar degrees of change and stability in the structure of political attention. To demonstrate this, the following analysis investigates the autoregressive character of agenda diversity: that is the degree to which issue diversity is stable over time. It uses tests for integrated time series and estimates an autoregressive distributed lag model to confirm that there is a similar degree of persistence in the level of issue diversity across countries. 
When plotted over time, entropy provides an indication of the persistence in diversity of the executive's attention across all topics on the agenda in each of the six countries (see Figure 1). No general pattern of change in agenda diversity is observable from cross-national comparison. In the parliamentary systems of Denmark, the Netherlands, Spain and the U.K., the levels of entropy fluctuate less clearly than in France and the U.S. The Netherlands, France and Spain also show some upward drift in agenda diversity.

To determine the time series characteristics of the agenda diversity series and to justify the pooling of this data, Augmented Dickey-Fuller (1979) tests for unit root in the levels and first differences are reported in Table $4 .^{6}$ All the test results reject the null of presence of unit root in agenda diversity. Exogenous shocks to diversity of the executive agenda do not appear to persist over time in any of the six countries. The significant coefficients for each of the countries reject the presence of a unit root in agenda diversity in each country. This suggests that agenda diversity of executive speeches is an autoregressive, stationary process that returns to its long-run equilibrium for each of the individual countries. These results confirm that the time series characteristics of agenda diversity are comparable across countries with the only notable difference being in the mean value of agenda diversity by country. The underlying dynamic of agenda diversity is the same in each of the six countries, with the only substantive difference being in the intercept (i.e. the mean level of issue diversity). This finding confirms the common structure of agenda diversity, which is important for comparative enquiry. It is also consistent with the decision to pool the cross-national data for analysis of the effect of issue attention on agenda diversity. 
[insert Table 4 about here]

The autoregressive character of agenda diversity can be further tested through estimation of a time series cross-sectional autoregressive distributed lag (ADL) model of agenda entropy. The cross-sectional data is organized in the form country $(i)$ * year $(t)$, with this model represented in the form $Y_{\text {it }}=\alpha_{0}+\alpha_{1} Y_{\text {it- }}$ ${ }_{1}+\varepsilon_{\mathrm{it}}$, where diversity $\left(\mathrm{Y}_{\mathrm{it}}\right)$ is a function of a constant term $\left(\alpha_{0}\right)$, plus some fraction $\left(\alpha_{1}\right)$ of past values of itself $\left(Y_{i t-1}\right)$ and a random shock $\left(\varepsilon_{i t}\right)$, including country fixed-effects to account for differences in the mean level of agenda entropy (taking the Netherlands, which has the highest mean in Table 3 as the base). ${ }^{7}$ This cross-sectional framework enables analysis of the general autoregressive character of agenda diversity (estimated using panel-corrected standard errors). This model specification assumes that agenda diversity exhibits persistence regardless of the characteristics of the political system, with institutional variations in the form of executive speeches reflected in the mean level of issue diversity.

[insert Table 5 about here]

The results presented in the first column of Table 5 ("AR"), confirm that agenda diversity is an autoregressive process of $0.3,{ }^{8}$ indicating that past values are predictive of its future values and that diversity is a partial function of past values subject to random errors, with finite variance between the lower and upper bounds of the entropy measure. This means that 30 per cent of the diversity of the executive agenda in year $t-1$ is carried forward into year $t$. These findings are 
consistent with the incremental evolution of agenda diversity over time reverting to the long-run equilibrium (i.e. mean) of entropy of the executive agenda. However, a coefficient of 0.3 for an autoregressive process is lower than might be expected. The autoregressive component of agenda diversity is not the only determinant of its future values.

The Effect of the Primary Functions of Government on Agenda Diversity $\left(H_{1}\right)$

To test $\mathrm{H}_{1}$ - that increases in attention to the core issues of the economy, international affairs, defence, government operations and law and order leads to a lower diversity of the executive agenda - the basic ADL model considered earlier is used. This is now represented in the form $Y_{i t}=\alpha_{0}+\alpha_{1} Y_{i t-1}+\beta_{1} X_{i t}+\beta_{2} C_{i t}+\beta_{3} D_{i t}$ $+\varepsilon_{\text {it }}$, where diversity $\left(\mathrm{Y}_{\mathrm{it}}\right)$ is a function of a constant term $\left(\alpha_{0}\right)$, plus some fraction $\left(\alpha_{1}\right)$ of past values of itself $\left(Y_{i t-1}\right)$, the level of attention to an issue $\left(X_{i t}\right)$, the number of executive statements per year $\left(\mathrm{C}_{\mathrm{it}}\right)$, a variable to control for partisan control of government $\left(\mathrm{D}_{\mathrm{it}}\right)$ and a random shock $\left(\varepsilon_{\mathrm{it}}\right)$. The variable is equal to 1 when a leftwing party controls government, is equal to 0 when a right-wing party controls government and is equal to 0.5 in those few cases where there is a left-right coalition in government. ${ }^{9}$ In this model specification, the effect of core issues on agenda diversity is expected to be negative $\left(\beta_{1}<0\right)$, indicating a decrease in the level of diversity.

The results for the time series cross-sectional analyses are presented in Table 5. These first of all indicate that, across all issues, there is no systematic evidence of a significant effect of partisan control of government on issue diversity. There are two minor exceptions to this. For the topic relating to space, science, technology and communications (17) the results suggest there is a 
positive and significant effect of partisan control of government $\left(0.054^{*}\right)$. However, this is most likely due to the very low frequency of mentions of this topic, where the disproportionate number of zeros across countries and over time on this issue means that variation from zero generates the spurious relationship between partisan control and issue diversity. In the case of foreign affairs (19), the results indicate that there is a near significant relationship $(0.040 \dagger)$ between partisan control of government and attention diversity. The most logical explanation for this is the difference between the amount of attention that left and right parties assign to foreign affairs. On average right governments mention foreign affairs significantly more than their left counterparts, which leads to a decrease in issue diversity. Overall, there is little evidence of partisan effects on issue diversity.

There is, however, a general positive effect of agenda size on issue diversity. The results in Table 5 indicate that the effect on agenda diversity of the number of executive statements $\left(0.001^{* * *}\right)$ is positive and significant at the 99 per cent confidence level, but quite small. For each additional statement that is included in an executive speech, there is on average a 0.001 increase in diversity of the executive agenda. Given the relative stability in the length of executive speeches noted earlier, the magnitude of this effect is minimal. It confirms the observation in description of Figure 1 that the agenda size of executive speeches in each of the six countries is largely stable over time in view of the extended time series.

[insert Table 5 about here] 
Turning next to the effect of specific policy topics on diversity of the executive agenda across the six countries, a distinct pattern emerges that is consistent with $\mathrm{H}_{1}$. The effect on agenda diversity is negative and significant at the 95 per cent level for four out of the five major topic codes associated with the core functions of government: macroeconomic issues (1), defence (16), foreign affairs (19) and government operations (20). This indicates that increases in executive attention to each of these topics leads to decreased agenda diversity. In other words, these core functions of government tend to crowd out attention to other topics, leading to decreased agenda diversity. When government attends to these core issues, the share of attention received by other issues drops making the overall diversity of issues dealt with narrower. The largest reduction in diversity is observed for international affairs $\left(-1.044^{* * *}\right)$, and the smallest effect is for government operations $\left(-0.495^{*}\right)$. For example, if the executive assigns $50 \%$ of attention to international affairs this is associated with a 0.522 decrease in diversity of the agenda $(0.5 *-1.044)$. Contrary to $\mathrm{H}_{1}$, law and order is positively signed $(0.527 \dagger)$ indicating an increase in diversity, but is only significant at the 90 per cent confidence level. This suggests that law and order, while a core function of government, may be selective for the executive agenda. Policing and criminal justice concerns might instead be attended to by other branches of government. Overall, the results confirm that when the economy, government operations, defence and international affairs are high on the agenda, the executive pursues a far less diverse agenda - focusing the majority of its attention on fewer issues. These findings are consistent with $\mathrm{H}_{1}$.

For the majority of topics, the effect of the number of topic mentions is positive and significantly greater than 0 at the 95 per cent confidence level. These 
topics are immigration and civil liberties (2), health (3), agriculture (4), education (6), environment (7), transport (10), welfare (13), housing (14), business and commerce (15) and telecommunications, science and technology (17) and public lands (21). For example, if the executive assigns $5 \%$ of its attention to education this is associated with a 0.08 increase in diversity of the agenda $(0.05 * 1.615)$. It follows that certain issues are associated with a more diverse agenda as the executive considers a broader range of issues. Some of these issue topics are characteristic of policy activities that are interlinked with a welfarist European model of the state, suggesting that increased diversity of the executive agendas is enabled at times when the core functions of government are lower on the agenda. Certain issues are therefore associated with a more diverse agenda, as government attention to core issues decreases, attention to these others issues increases.

What might explain such a pattern of agenda-setting? The autoregressive character of agenda diversity may be a result of attention-trading between issues. For instance, executive attention might be transferred from international affairs to defence during wartime with no effect upon issue diversity of the agenda (see Examples 3 and 4 in Table 2). Such attention shifts could occur between selective issues - generating either negative or insignificant effects upon agenda diversity. The results here suggest that changes in the level of government attention to particular issues do, in fact, have an effect on the level of agenda diversity. Combined, these findings provide strong evidence in support of $\mathrm{H}_{1}$ : the core functions of government theory of executive agenda-setting. The results for the effect on agenda diversity of core policy issues are notable in their direction and magnitude. The level of attention to most issues has consequences for the overall distribution of the executive agenda. ${ }^{10}$ There is a long-run equilibrium in agenda 
diversity of executive speeches across countries and negative effects of core issues on diversity. Attention of government to selective issues tend to gain access to the agenda when its core functions are less urgent, leading to greater agenda diversity.

\section{Conclusion}

This analysis has sought to model and explain the diversity of executive agendas in six countries - Denmark, France, the Netherlands, Spain, the U.K. and the U.S. - that exhibit variation in both their political system and their form of government. Using unit root tests and time series cross-sectional analyses it has considered the long-run equilibrium of agenda diversity and the effects of the core functions of government on executive agendas presented in annual speeches of policy priorities and intentions. The results indicate that the diversity of executive agendas across countries, while having different means, exhibits a similar pattern of persistence following a long-run equilibrium in all of the six countries. The issue diversity of the executive agenda does not appear to be punctuated by shocks in attention to specific issues as is the case within policy domains (e.g. Baumgartner and Jones 1993). Even when there are disproportionate adjustments in attention, the overall diversity of the agenda does experience a similar degree of change. The results for our hypothesis $\left(\mathrm{H}_{1}\right)$ offer strong evidence of the limiting effect of core issues - the economy, government operations, defence and international affairs - on agenda diversity. This suggests that not only do some issues receive more attention than others, but certain issues receive attention at the expense of others. There is a trade-off between government attention to core issues and to selective issues, where some issues crowd out others. When the core functions of government are high on the political agenda, the limited institutional 
capacity of the agenda allows the executive to pursue far less diverse portfolio of issues - focusing most of its attention on fewer issues outside its immediate concerns.

The findings suggest that this crowding-out phenomenon occurs between core and selective issues, but not between core issues. This indicates that when a core issue receives more attention from the executive, it is not at the expense of other core issues but rather occupies space on the agenda previously taken by selective issues and vice versa. The core functions of government are those issues with a preeminent status in politics. These main responsibilities of the state are to defend its territory, interact with other states, manage the well-being of its citizens and maintain the state apparatus itself. Historically, these core issues have tended to dominate the agendas of governments. The negative effects of the core functions of government on agenda diversity are not due to the higher than average mean level of attention alone, but rather indicate that these issues take attention away from selective issues but not each other. This is consistent with the pattern of change in agenda diversity in the move from Example 3 to 2 in Table 2. When selective issues receive an increased amount of executive attention this occurs at times when core issues are less salient and does not tend to be at the expense of each other. These instead occupy space on the agenda that otherwise tends to be assigned to core issues (this is indicated by the positive coefficients in Table 5). From the evidence reported here, the relationship between these core issues and selective issues appears to be unequal.

In contrast, the results of the analysis suggest that, in general, partisan control of government does not have a direct effect on issue diversity. These effects are instead mediated through partisan differences in attention to particular 
topics. There is no systematic difference in the structure of the executive agendas of left- and right-wing governments. The findings also indicate that the size of the executive agenda has a positive and significant effect upon issue diversity of the agenda, but this effect is small in magnitude. While there are differences in the average level of agenda diversity across countries, the findings show that there is a general pattern of diversity for all countries.

The dynamics of agenda diversity across the six countries that have been considered in this analysis suggests that the attention of government in annual statements of executive agendas is driven by the prioritization of issues in view of information about the state of the world. The importance of the core functions of government conditions the amount of agenda space available to other issues. In contrast, party control of government does not systematically influence the degree of issue diversity of these executive agendas. To understand the structure of attention to one issue, it is necessary to understand the general distribution of attention across all issues due to the finite nature of attention for the executive agenda. Such governing agendas are subject to general characteristics of bounded rationality and the limits of parallel-processing in an information-rich world (Simon 1971; Jones 1994).

This finding has broad implications for the study of issue attention within governments and within other political institutions engaged in the prioritization of policy problems. It is of general consequence for the agendas of political actors and institutions; such as parties and their electoral platforms, the programmes of executive governments, bureaucratic subsystems, legislatures, and so forth. The comparative analysis of agenda diversity and the nature of its dynamics can, 
therefore, contribute to a wider understanding of the content of political debate and action.

To achieve a better understanding of the determinants of agenda diversity, further comparative analysis is required of executive, legislative, public and media agendas - across a range of political systems. The finding that the core functions of government structure attention of the executive to all issues within the scope of democratic governments warrants further investigation. Studies of agenda-setting and issue attention of government generally do not control for the interrelationship between issues. Studies of political attention to specific issues do not tend to consider the effects that other issues have on the allocation of attention. The attention of government to a particular issue depends on the structure of its attention to all issues across the agenda. This seems to be less driven by partisan choice due to the composition of these governments and more associated with the responses to signals relating to the core state functions. While an issue might be marginalised due to the prominence of other issues on the agenda, at another time or in another country the same issue might receive more attention as others issues take up less of the agenda. For example, the events of the Credit Crunch have shifted attention of government away from the environment towards the economy. This analysis of long-run equilibrium in agenda diversity and the effect of core functions government on agenda diversity, as well as the space available for attention to selective issues, provides an important caveat for future studies of agenda-setting. The common structure and behaviour of these governing agendas is important for future comparative political analysis, contributing further to understanding of similarities in government decision-making across countries (e.g. Baumgartner et al. 2009; Jones et al. 2009a). How government assigns its 
attention is central to the function of political systems and the responsiveness of institutions. Future research in this area might consider the structure of attention for other institutional agendas - such as for legislatures or bureaucracies - and how partisan control of government otherwise affects the content and dynamics of governing agendas.

The findings also suggest that within-domain studies of agenda-setting would be advised to consider the degree to which agenda-change is associated with the overall structure of political attention. Studies such as Downs' (1972) classic explanation of the ebb and flow of attention to environmental issues often do not look outside the policy domain in question to understand changes in government attention. Our findings suggest that governments' allocation of attention to a single issue is conditional on their attention to all issues. For example, the recent relative decline in attention to climate change might in part be due to logics internal to the policy domain, but to a great extent is attributable to changes in other domains - in particular the world macro-economy. 


\section{References}

Bara, Judith. 2005. 'A Question of Trust: Implementing Party Manifestos.'

Parliamentary Affairs 58(3): 585-599.

Baumgartner, Frank R., Christian Breunig, Christoffer Green-Pedersen, Bryan D. Jones, Peter B. Mortensen, Michiel Neytemans and Stefaan Walgrave. 2009. 'Punctuated Equilibrium in Comparative Perspective.' American Joumal of Political Science 53(3): 602-619.

Baumgartner, Frank R., Martial Foucault, and Abel François. 2006. 'Punctuated Equilibrium in French Budgeting Processes.' Journal of European Public Policy 13(7): 1082-1099.

Baumgartner, Frank R. and Bryan Jones. 1991. "Agenda Dynamics and Policy Subsystems." The Journal of Politics 53(4): 1044-1074.

Baumgartner, Frank R., and Bryan Jones. 1993. Agendas and Instability in American Politics. Chicago: University of Chicago Press.

Baumgartner, Frank R., Bryan Jones, and Michael C. MacLeod. 1998. "Lessons from the Trenches: Quality, Reliability, and Usability in a New Data Source." The Political Methodologist 8(2): 1-11.

Baumgartner, Frank R., Bryan Jones, and Michael C. MacLeod. 2000. "The Evolution of Legislative Jurisdictions." The Journal of Politics 62(2): 321-349.

Breeman, Gerard, David Lowery, Caelesta Poppelaars, Sandra L. Resodihardjo, Arco Timmermans and Jouke de Vries. 2009. "Political Attention in a Coalition System: Analyzing Queen's Speeches in the Netherlands 1945-2007." Acta Politica 44(1): 1-27. 
Breunig, Christian. 2006. "The More Things Change, the More Things Stay the Same: A Comparative Analysis of Budget Punctuations." Journal of European Public Policy 13(7): 1069-1085.

Brouard, Sylvain, John Wilkerson, Frank R. Baumgartner, Arco Timmermans, Shaun Bevan, Gerard Breeman, Christian Breunig, Laura Chaqués, Christopher Green-Pedersen, Will Jennings, Peter John, Bryan D. Jones, David Lowery. 2009. “Comparer Les Productions Législatives : Enjeux Et Méthodes." Revue Internationale de Politique Comparée. 16(3): 381-404. Budge, Ian, and Dennis Farlie. 1983. 'Party Competition - Selective Emphasis or Direct Confrontation? An Alternative View with Data,' pp. 267-305 in Hans Daalder and Peter Mair (eds.). West European Party Systems. Continuity \& Change. London: Sage Publications.

Budge, Ian, Hans-Dieter Klingeman, Andrea Volkens, Judith Bara \& Eric Tanenbaum. 2001. Mapping Policy Preferences. Estimates for Parties, Electors, and Governments 1945-1998. Oxford: Oxford University Press.

Budge, Ian, and Richard I Hofferbert. 1990. "Mandates and Policy Outputs: U.S. Party platforms and Federal Expenditures." American Political Science Review 84(1): 111-132.

Budge, Ian, and Richard I. Hofferbert. 1992. "The Party Mandate and the Westminster Model: Party Programmes and Government Spending in Britain, 1948-1985." British Journal of Political Science 22(2): 151-182.

Cohen, Bernard. 1963. The Press and Foreign Policy. Princeton, NJ: Princeton University Press. 
Cohen, Jeffrey E. 1995. "Presidential Rhetoric and the Public Agenda." American Journal of Political Science 39(1): 87-107.

Cohen, Jeffrey E. 1997. Presidential Responsiveness and Public Policy-Making: The Publics and the Policies that Presidents Choose. Ann Arbor: University of Michigan Press.

Cox, G. W. (1997). Making Votes Count: Strategic Coordination in the World's Electoral Systems. Cambridge: Cambridge University Press.

Dickey, David A., and Wayne A. Fuller. 1979. "Distribution of the Estimators for Autoregressive Time Series with a Unit Root." Joumal of the American Statistical Association 74(366): 427-431.

Downs, Anthony. 1972. "Up and Down with Ecology: The Issue-Attention Cycle." The Public Interest 28(Summer): 38-50.

Green-Pedersen, Christoffer. 2007. "The Growing Importance of Issue Competition: The Changing Nature of Party Competition in Western Europe." Political Studies 55(3): 607-628.

Grossback, David, David Peterson, and James Stimson. 2006. Mandate Politics. Cambridge: Cambridge University Press.

Edwards, George C. III and Andrew Barrett. 2000. "Presidential Agenda-Setting in Congress." In Polarized Politics: Congress and the President in a Partisan Era. eds. Jon R. Bond and Richard Fleischer. Washington, DC: CQ Press.

Hobbes, Thomas. 1651. Leviathan. 
Hobolt, Sara B., and Robert Klemmensen. 2005. "Responsive Government? Public Opinion and Government Policy Preferences in Britain and Denmark." Political Studies 53(2): 379-402.

Hobolt, Sara B., and Robert Klemmensen. 2008. "Government Responsiveness and Political Competition in Comparative Perspective." Comparative Political Studies 41(3): 309-337.

Jennings, Will, and Peter John. 2009. "The Dynamics of Political Attention: Public Opinion and the Queen's Speech in the United Kingdom." American Journal of Political Science 53(4): 838-854.

John, Peter, and Helen Margetts. 2003. "Policy Punctuations in the UK: Fluctuations and Equilibria in Central Government Expenditure since 1951." Public Administration 81(3): 411-432.

Jochen, Peter, and Claes H. De Vreese. 2003. "Agenda-Rich, Agenda-Poor: A Cross-National Comparative Investigation of Nominal and Thematic Public Agenda Diversity." International Journal of Public Opinion Research 15: 44-64.

Jones, Bryan. 1994. Reconceiving Decision-making in Democratic Politics: Attention, Choice, and Public Policy. Chicago: University of Chicago Press.

Jones, Bryan D., Frank R. Baumgartner, and James L. True. 1998. "Policy Punctuations: U.S. Budget Authority, 1947-1995." The Journal of Politics 60(1): $1-33$.

Jones, Bryan D., and Frank R. Baumgartner. 2005. The Politics of Attention: How Government Prioritizes Problems. Chicago: University of Chicago Press.

Jones, Bryan D., Frank R. Baumgartner, Christian Breunig, Christopher Wlezien, Stuart Soroka, Martial Foucault, Abel François, Christoffer Green-Pedersen, 
Peter John, Chris Koski, Peter B. Mortensen, Frédéric Varone, and Stefaan

Walgrave. 2009a. "A General Empirical Law of Public Budgets: A

Comparative Analysis." American Journal of Political Science 53(4): 855-873.

Jones, Bryan D., Heather Larsen-Price, and John Wilkerson. 2009b.

"Representation and American Governing Institutions." Journal of Politics 71: 277-290.

Jones, Bryan D., Tracy Sulkin, and Heather Larsen. 2003. "Policy Punctuations in American Political Institutions." American Political Science Review 97(1): 151169.

Kingdon, John. 1984. Agendas, Alternatives and Public Policies. New York: HarperCollins.

Klingemann, Hans-Dieter, Richard I. Hofferbert and Ian Budge. 1994. Parties, Policies and Democracy, Boulder: Westview Press.

Lijphart, A. (1994). Electoral Systems and Party Systems: A Study of Twenty-Seven Democracies, 1945-1990. Oxford: Oxford University Press.

Lijphart, A. (1999). Government Forms and Performance in Thirty-Six Countries. New Haven: Yale University Press.

Locke, John. 1689. Two Treatises of Government.

McCombs, Maxwell, and Zhu Jian-Hua. 1995. "Capacity, Diversity, and Volatility of the Public Agenda: Trends from 1954-1994.” Public Opinion Quarterly 59(4): 495-517.

McCombs, Maxwell E., and Donald L. Shaw. 1972. "The Agenda-Setting Function of Mass Media." Public Opinion Quarterly 36(2): 176-187. 
McDonald, Michael D., and Ian Budge. 2005. Elections, Parties, Democracy. Oxford: Oxford University Press.

Müller, Wolfgang C., and Kaare. Strøm. 2008. "Coalition Agreements and Cabinet Governance." In Cabinets and Coalition Bargaining. The Democratic Life Cycle in Western Europe. eds. Kaare Strøm, Wolfgang C. Müller and Torbjörn Bergman. Oxford: Oxford University Press.

North, Douglass C. 1990. Institutions, Institutional Change, and Economic Performance. Cambridge: Cambridge University Press

Petrocik, John. 1996. "Issue-Ownership in Presidential Elections with a 1980 Case Study." American Journal of Political Science 40(3): 825-850.

Phillips, Peter C.B, and Pierre Perron. 1988. "Testing for a Unit Root in Time Series Regressions." Biometrika 75(2): 335-346.

Pierson, Paul. 2000. "Path Dependence, Increasing Returns, and the Study of Politics." American Political Science Review 94(2): 251-267.

Powell, G. Bingham. (2000). Elections as Instruments of Democracy: Majoritarian and Proportional Views. New Haven: Yale University Press.

Riker, William H. 1986. The Art of Political Manipulation. New Haven: Yale University Press.

Schattschneider, Elmer E. 1960. The Semi-Sovereign People: A Realist's View of Democracy in America. New York: Holt, Rinehart and Winston.

Shannon, Claude E. 1948. "A Mathematical Theory of Communication." Bell System Technical Journal 27(July): 379-423; 27(October): 623-656.

Simon, Herbert A. 1957. Models of Man. New York: John Wiley. 
Simon, Herbert A. 1971. "Designing Organizations for an Information-Rich World." In Computers, Communication, and the Public Interest. ed. Martin Greenberger. Baltimore, MD: Johns Hopkins Press.

Soroka, S. and C. Wlezien (2010), Politics, Public Opinion, and Policy. Cambridge: Cambridge University Press.

Strøm, Kaare. 2000. "Delegation and accountability in parliamentary democracies." European Journal of Political Research 37 (May): 261-289.

Strøm, Kaare. 2003. "Parliamentary Democracy and Delegation." in Delegation and Accountability in Parliamentary Democracies. Strøm, Muller, and Bergman, eds. Oxford: Oxford University Press.

Timmermans, Arco. 2006. "Standing Apart and Sitting Together. Enforcing Coalition Agreements in Multiparty Systems." European Journal of Political Research 45(2): 263-283.

True, James L., Bryan D. Jones and Frank R. Baumgartner. 2007. "PunctuatedEquilibrium Theory: Explaining Stability and Change in American Policymaking." In Theories of the Policy Process (Second Edition). ed. Paul Sabatier. Boulder: Westview Press.

Rousseau, Jean-Jacques. 1762. The Social Contract.

Shepsle, Kenneth, and Barry Weingast. 1984. "Uncovered Sets and Sophisticated Voting Outcomes with Implications for Agenda Institutions." American Joumal of Political Science 28(1): 49-74.

Volkens, Andrea. 2000. Manifesto Coding Instructions. Discussion Paper FS III 02-201. Berlin: WZB. 
Wilson, Woodrow. 1889. The State. Boston: D. C. Heath. 
FIGURES AND TABLES

Table 1. The Policy Agendas Project Major Topic Codes

1. Macroeconomics

2. Civil Rights, Minority Issues, and Civil Liberties

3. Health

4. Agriculture

5. Labour, Employment and Immigration

6. Education

7. Environment

8. Energy

10. Transportation

12. Law, Crime and Family Issues

13. Social Welfare

14. Housing and Urban Development

15. Banking, Finance, and Domestic Commerce

16. Defence

17. Space, Science, Technology and Communications

18. Foreign Trade

19. International Affairs and Foreign Aid

20. Government Operations

21. Public Lands and Water Management 
Table 2. An Illustration of Calculation of Agenda Entropy

\begin{tabular}{|c|c|c|c|c|c|c|c|c|c|}
\hline Example & Issue & & & & & & & & Entropy \\
\hline & $\mathbf{A}$ & B & C & D & $\mathbf{E}$ & $\mathbf{F}$ & $\mathbf{G}$ & Total & \\
\hline 1 & $100 \%$ & $0 \%$ & $0 \%$ & $0 \%$ & $0 \%$ & $0 \%$ & $0 \%$ & $100 \%$ & 0 \\
\hline 2 & $75 \%$ & $25 \%$ & $0 \%$ & $0 \%$ & $0 \%$ & $0 \%$ & $0 \%$ & $100 \%$ & 0.56 \\
\hline 3 & $50 \%$ & $25 \%$ & $5 \%$ & $5 \%$ & $5 \%$ & $5 \%$ & $5 \%$ & $100 \%$ & 1.44 \\
\hline 4 & $25 \%$ & $50 \%$ & $5 \%$ & $5 \%$ & $5 \%$ & $5 \%$ & $5 \%$ & $100 \%$ & 1.44 \\
\hline 5 & $25 \%$ & $25 \%$ & $10 \%$ & $10 \%$ & $10 \%$ & $10 \%$ & $10 \%$ & $100 \%$ & 1.84 \\
\hline 6 & $14.3 \%$ & $14.3 \%$ & $14.3 \%$ & $14.3 \%$ & $14.3 \%$ & $14.3 \%$ & $14.3 \%$ & $100 \%$ & 1.95 \\
\hline
\end{tabular}


Table 3. Entropy of Executive Speeches

\begin{tabular}{|l|l|l|l|l|l|l|l|l|l|l|}
\hline & $\begin{array}{l}\text { Political } \\
\text { System }\end{array}$ & Start & End & $\mathbf{n}$ & $\begin{array}{l}\text { Entropy: } \\
\text { Mean }\end{array}$ & $\begin{array}{l}\text { Entropy: } \\
\text { S.D. }\end{array}$ & $\begin{array}{l}\text { Entropy: } \\
\text { Min }\end{array}$ & $\begin{array}{l}\text { Entropy: } \\
\text { Max }\end{array}$ & $\begin{array}{l}\text { Number of } \\
\text { Policy } \\
\text { Statements: } \\
\text { Mean }\end{array}$ & $\begin{array}{l}\text { Number of } \\
\text { Policy } \\
\text { Statements: } \\
\text { S.D. }\end{array}$ \\
\hline UK & Parliamentary & 1945 & 2008 & 64 & 2.401 & 0.167 & 1.997 & 2.659 & 72.672 & 14.878 \\
\hline Netherlands & Parliamentary & 1945 & 2007 & 63 & 2.438 & 0.219 & 1.733 & 2.734 & 126.191 & 45.658 \\
\hline Denmark & Parliamentary & 1953 & 2006 & 54 & 2.294 & 0.264 & 1.484 & 2.607 & 235.370 & 71.740 \\
\hline Spain & Parliamentary & 1982 & 2007 & 26 & 2.154 & 0.266 & 1.538 & 2.538 & 280 & 51.584 \\
\hline US & Presidential & 1946 & 2005 & 60 & 2.116 & 0.331 & 1.208 & 2.670 & 268.167 & 216.326 \\
\hline France & $\begin{array}{l}\text { Semi- } \\
\text { Presidential }\end{array}$ & 1958 & 2006 & 49 & 1.797 & 0.374 & 0.695 & 2.375 & 42.224 & 20.528 \\
\hline
\end{tabular}


Table 4. Unit Root Test Results for the Entropy of Executive Speeches

\begin{tabular}{|c|c|c|c|c|c|c|}
\hline & $\begin{array}{l}\text { United } \\
\text { Kingdom }\end{array}$ & Netherlands & Denmark & Spain & $\begin{array}{l}\text { United } \\
\text { States }\end{array}$ & France \\
\hline \multicolumn{7}{|c|}{ Augmented Dickey-Fuller (ADF) Test Statistic (Levels) } \\
\hline Random Walk & $-4.524^{* * *}$ & $-4.228^{* * *}$ & $-4.531^{* * *}$ & $-3.090 * *$ & $-7.196^{* * *}$ & $-4.256^{* * *}$ \\
\hline Trend & $-4.476^{* * *}$ & $-5.463^{* * *}$ & $-4.640^{* * *}$ & $-4.351^{* *}$ & $-7.134^{* * *}$ & $-4.727^{* * *}$ \\
\hline \multicolumn{7}{|c|}{ Augmented Dickey-Fuller (ADF) Test Statistic (First Difference) } \\
\hline Random Walk & $-10.500^{* * *}$ & $-9.608^{* * *}$ & $-8.762^{* * *}$ & $-10.524^{* * *}$ & $-12.687^{* * *}$ & $-11.538^{* * *}$ \\
\hline Trend & $-10.384^{* * *}$ & $-9.552^{* * *}$ & $-8.673^{* * *}$ & $-10.353^{* * *}$ & $-12.572^{* * *}$ & $-11.451^{* * *}$ \\
\hline $\mathrm{N}$ & 64 & 63 & 54 & 26 & 60 & 49 \\
\hline Start & 1945 & 1945 & 1953 & 1982 & 1946 & 1958 \\
\hline End & 2008 & 2007 & 2006 & 2007 & 2005 & 2006 \\
\hline
\end{tabular}

${ }^{*} \mathrm{p}<.1,{ }^{* *} \mathrm{p}<.05, * * * \mathrm{p}<.01$ 
Table 5. Time Series Cross-Sectional Autoregressive Distributed Lag Model of Agenda Entropy, Issue Intrusion and Agenda Capacity with Country Fixed Effects (omitted from this table 11)

\begin{tabular}{|c|c|c|c|c|c|c|c|c|c|c|}
\hline & AR & 1 & 2 & 3 & 4 & 5 & 6 & 7 & 8 & 10 \\
\hline L.Entropy & $\begin{array}{c}0.348^{* * *} \\
(0.055)\end{array}$ & $\begin{array}{c}0.331^{* * *} \\
(0.056)\end{array}$ & $\begin{array}{c}0.329^{* * *} \\
(0.054)\end{array}$ & $\begin{array}{c}0.333^{* * *} \\
(0.053)\end{array}$ & $\begin{array}{c}0.341^{* * *} \\
(0.054)\end{array}$ & $\begin{array}{c}0.341^{* * *} \\
(0.055)\end{array}$ & $\begin{array}{c}0.304^{* * *} \\
(0.052)\end{array}$ & $\begin{array}{c}0.335^{* * *} \\
(0.053)\end{array}$ & $\begin{array}{c}0.348^{* * *} \\
(0.055)\end{array}$ & $\begin{array}{c}0.300^{* * *} \\
(0.054)\end{array}$ \\
\hline Issue & & $\begin{array}{c}-0.573^{* *} \\
(0.184)\end{array}$ & $\begin{array}{c}1.692^{* * *} \\
(0.514)\end{array}$ & $\begin{array}{c}1.757^{* * *} \\
(0.428)\end{array}$ & $\begin{array}{c}2.156^{* * *} \\
(0.428)\end{array}$ & $\begin{array}{c}0.227 \\
(0.245)\end{array}$ & $\begin{array}{c}1.615^{* * *} \\
(0.348)\end{array}$ & $\begin{array}{l}1.399 * * \\
(0.543)\end{array}$ & $\begin{array}{l}-0.131 \\
(0.390)\end{array}$ & $\begin{array}{c}3.529 * * * \\
(0.559)\end{array}$ \\
\hline Left & $\begin{array}{c}0.019 \\
(0.025)\end{array}$ & $\begin{array}{c}0.001 \\
(0.026)\end{array}$ & $\begin{array}{c}0.011 \\
(0.025)\end{array}$ & $\begin{array}{c}0.005 \\
(0.026)\end{array}$ & $\begin{array}{c}0.015 \\
(0.024)\end{array}$ & $\begin{array}{c}0.017 \\
(0.025)\end{array}$ & $\begin{array}{c}0.022 \\
(0.025)\end{array}$ & $\begin{array}{c}0.023 \\
(0.024)\end{array}$ & $\begin{array}{c}0.019 \\
(0.025)\end{array}$ & $\begin{array}{l}-0.005 \\
(0.025)\end{array}$ \\
\hline Statements & $\begin{array}{c}0.001^{* * *} \\
(0.000)\end{array}$ & $\begin{array}{c}0.001^{* * *} \\
(0.000)\end{array}$ & $\begin{array}{c}0.001^{* * *} \\
(0.000)\end{array}$ & $\begin{array}{c}0.001^{* * *} \\
(0.000)\end{array}$ & $\begin{array}{c}0.001^{* * *} \\
(0.000)\end{array}$ & $\begin{array}{c}0.001^{* * *} \\
(0.000)\end{array}$ & $\begin{array}{c}0.001^{* * *} \\
(0.000)\end{array}$ & $\begin{array}{c}0.001^{* * *} \\
(0.00)\end{array}$ & $\begin{array}{c}0.001^{* * *} \\
(0.000)\end{array}$ & $\begin{array}{c}0.001^{* * *} \\
(0.000)\end{array}$ \\
\hline Constant & $\begin{array}{c}1.459^{* * *} \\
(0.135)\end{array}$ & $\begin{array}{c}1.618^{* * *} \\
(0.149)\end{array}$ & $\begin{array}{c}1.477^{* * *} \\
(0.133)\end{array}$ & $\begin{array}{c}1.468^{* * *} \\
(0.13)\end{array}$ & $\begin{array}{c}1.416^{* * *} \\
(0.134)\end{array}$ & $\begin{array}{c}1.459^{* * *} \\
(0.135)\end{array}$ & $\begin{array}{c}1.488^{* * *} \\
(0.127)\end{array}$ & $\begin{array}{c}1.462^{* * *} \\
(0.130)\end{array}$ & $\begin{array}{c}1.461^{* * *} \\
(0.135)\end{array}$ & $\begin{array}{c}1.477^{* * *} \\
(0.131)\end{array}$ \\
\hline $\mathrm{R}^{2}$ & 0.517 & 0.535 & 0.544 & 0.538 & 0.539 & 0.518 & 0.552 & 0.530 & 0.517 & 0.552 \\
\hline & 12 & 13 & 14 & 15 & 16 & 17 & 18 & 19 & 20 & 21 \\
\hline L.Entropy & $\begin{array}{c}0.329^{* * *} \\
(0.054)\end{array}$ & $\begin{array}{c}0.326^{* * *} \\
(0.056)\end{array}$ & $\begin{array}{c}0.339^{* * *} \\
(0.052)\end{array}$ & $\begin{array}{c}0.347^{* * *} \\
(0.053)\end{array}$ & $\begin{array}{c}0.332^{* * *} \\
(0.054)\end{array}$ & $\begin{array}{c}0.296^{* * *} \\
(0.050)\end{array}$ & $\begin{array}{c}0.35^{* * *} \\
(0.055)\end{array}$ & $\begin{array}{c}0.234^{* * *} \\
(0.046)\end{array}$ & $\begin{array}{c}0.346^{* * *} \\
(0.055)\end{array}$ & $\begin{array}{c}0.344^{* * *} \\
(0.055)\end{array}$ \\
\hline Issue & $\begin{array}{l}0.527 \dagger \\
(0.280)\end{array}$ & $\begin{array}{l}1.124^{* *} \\
(0.366)\end{array}$ & $\begin{array}{c}2.682^{* * *} \\
(0.461)\end{array}$ & $\begin{array}{l}2.96^{* * *} \\
(0.494)\end{array}$ & $\begin{array}{l}-0.514^{*} \\
(0.211)\end{array}$ & $\begin{array}{c}3.949 * * * \\
(0.676)\end{array}$ & $\begin{array}{c}0.322 \\
(0.445)\end{array}$ & $\begin{array}{c}-1.044^{* * *} \\
(0.119)\end{array}$ & $\begin{array}{l}-0.495^{*} \\
(0.208)\end{array}$ & $\begin{array}{l}1.225^{* *} \\
(0.439)\end{array}$ \\
\hline Left & $\begin{array}{c}0.020 \\
(0.025)\end{array}$ & $\begin{array}{c}0.015 \\
(0.026)\end{array}$ & $\begin{array}{l}-0.007 \\
(0.024)\end{array}$ & $\begin{array}{c}0.020 \\
(0.024)\end{array}$ & $\begin{array}{c}0.020 \\
(0.026)\end{array}$ & $\begin{array}{l}0.054^{*} \\
(0.024)\end{array}$ & $\begin{array}{c}0.020 \\
(0.025)\end{array}$ & $\begin{array}{l}0.040 \dagger \\
(0.020)\end{array}$ & $\begin{array}{c}0.015 \\
(0.025)\end{array}$ & $\begin{array}{c}0.025 \\
(0.026)\end{array}$ \\
\hline Statements & $\begin{array}{c}0.001^{* * *} \\
(0.00)\end{array}$ & $\begin{array}{c}0.001^{* * *} \\
(0.00)\end{array}$ & $\begin{array}{c}0.001^{* * *} \\
(0.00)\end{array}$ & $\begin{array}{c}0.001^{* * *} \\
(0.00)\end{array}$ & $\begin{array}{c}0.001^{* * *} \\
(0.00)\end{array}$ & $\begin{array}{c}0.001^{* * *} \\
(0.00)\end{array}$ & $\begin{array}{c}0.001^{* * *} \\
(0.00)\end{array}$ & $\begin{array}{c}0.001^{* * *} \\
(0.00)\end{array}$ & $\begin{array}{c}0.001^{* * *} \\
(0.00)\end{array}$ & $\begin{array}{c}0.001^{* * *} \\
(0.00)\end{array}$ \\
\hline Constant & $\begin{array}{c}1.488^{* * *} \\
(0.132)\end{array}$ & $\begin{array}{c}1.449^{* * *} \\
(0.136)\end{array}$ & $\begin{array}{c}1.369^{* * *} \\
(0.133)\end{array}$ & $\begin{array}{c}1.373^{* * *} \\
(0.131)\end{array}$ & $\begin{array}{c}1.524^{* * *} \\
(0.136)\end{array}$ & $\begin{array}{c}1.515^{* * *} \\
(0.122)\end{array}$ & $\begin{array}{c}1.443^{* * *} \\
(0.136)\end{array}$ & $\begin{array}{l}1.93^{* * *} \\
(0.122)\end{array}$ & $\begin{array}{c}1.502^{* * *} \\
(0.136)\end{array}$ & $\begin{array}{c}1.447^{* * *} \\
(0.135)\end{array}$ \\
\hline $\mathrm{R}^{2}$ & 0.522 & 0.533 & 0.551 & 0.546 & 0.524 & 0.562 & 0.518 & 0.602 & 0.528 & 0.525 \\
\hline
\end{tabular}

Note: Netherlands is selected as the base so the constant provides an estimation of the mean level of entropy

Panel-corrected standard errors for all time series cross-sectional models.

$\mathrm{N}=310,{ }^{*} \mathrm{p} \leq .05,{ }^{* *} \mathrm{p} \leq .01,{ }^{* * *} \mathrm{p} \leq .001, \dagger \mathrm{p} \leq 0.10$ 
Figure 1. Policy Content and Issue Diversity of Executive Speeches in Denmark, France, the Netherlands, Spain, the UK and the US
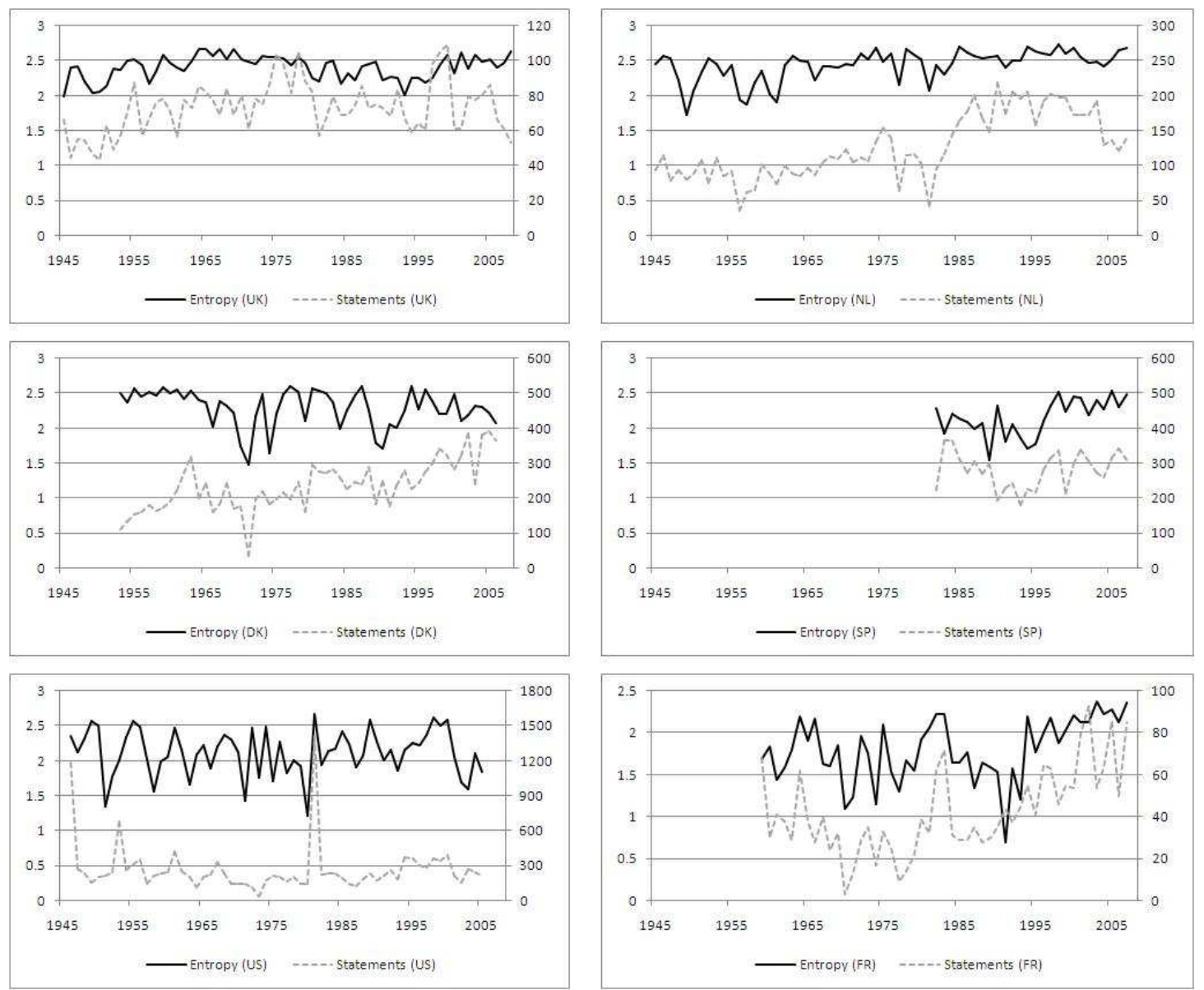
${ }^{1}$ Studies from the U.S. provide empirical evidence in support for this attention-based model. The reaction of policy-makers to information follows a pattern of proportionate and linear increments interrupted by disproportionate responses (Baumgartner and Jones 1991; 1993; Jones et al. 1998; 2003; Jones and Baumgartner 2005). Further research on policy agendas, legislative outputs and budget allocations in the U.S. and a number of European countries including Belgium, France, Denmark, Germany, the Netherlands and the United Kingdom have also shown non-normal distributions of attention (see Baumgartner et al. 2006; 2009; Breeman et al. 2009; Breunig 2006; John and Jennings 2009; John and Margetts 2003).

${ }^{2}$ A quasi-sentence (or policy statement) constitutes an expression of a single policy idea or issue (see Volkens 2002). Often this unit of analysis is identifiable from the use of punctuation, though it is possible for sentences to include multiple references to policy content (in particular those which address a series of major policy issues).

${ }^{3}$ While the Herfindahl index of firm-market concentration used in other studies of policy agendas (e.g. Baumgartner et al. 2000) is highly correlated to Shannon's H, it possesses less power at high levels of entropy - detecting less variation when attention is fragmented. Shannon's H is, therefore, most appropriate for analysis of dispersion of executive promises and priorities.

${ }^{4}$ Note that the U.S. data includes two State of the Union speeches in the years 1953 and 1961 where both the outgoing and incoming president gave a speech within a month of one another. There are no theoretical reasons for excluding one or other of these speeches, to these are retained and there is an amplification of the number of policy statements in these years. Removing either the two outgoing on incoming speeches does not alter the results.

${ }^{5}$ A specific code was assigned where there was no policy content whatsoever, such as for ceremonial statements or very general statements. The proportion of non-policy 
statements in each speech is, in ascending order, $28 \%$ for France, $17 \%$ for the US, $15 \%$ for Spain, $9 \%$ for the Netherlands, $8 \%$ for the UK and $4 \%$ for Denmark. This variation reflects cross-national differences in the institutional format and style of the speeches but does not detract from comparison of policy content.

${ }^{6}$ Using the Phillips-Perron (1989) test produces the same inferences concerning the presence of unit root.

${ }^{7}$ Choosing other omitted categories as the base value has no effect either on the AR parameter or on the relative relationship between countries average level of entropy, as would be expected.

${ }^{8}$ When estimated as individual country models, the entropy of the U.S. State of the Union Speech is problematic in terms of time series diagnostics. According to a LjungBox $Q$ test it is not white noise $\left(\chi^{2}=26.820\right)$, nor does it appear to be an autoregressive, $A R(p)$, process of any order of note or indeed a moving average, MA(q), process of any discernable order.

${ }^{9}$ This occurs for two years in Denmark (1978-1979) and for eight years in the Netherlands (1994-2001).

${ }^{10}$ The same general inferences are obtained for the majority of the results, both through different temporal samples and when dropping individual countries (i.e. jack-knifing). The only notable differences through dropping countries from the analyses are:

- Topic 1: if Denmark is excluded from the analysis, the coefficient direction is still negative, but the significance is lower $(p=0.095)$.

- Topic 5: if Spain is excluded from analysis, the coefficient direction is still positive but now significant $(p=0.008)$.

- Topic 8: if the U.S. is excluded from analysis, the coefficient direction is different (now negative) and now near significant $(\mathrm{p}=0.091)$.

- Topic 12: if the U.S. is excluded from analysis, the coefficient direction is the same (positive), but insignificant ( $\mathrm{p}=0.931)$. 
- Topic 16: if the U.S. is excluded from analysis, the coefficient direction is different (positive) and insignificant $(\mathrm{p}=0.926)$.

${ }^{11}$ Except for the UK, all country fixed effects were negative and significantly different than the base country, The Netherlands indicating a lower mean level of entropy controlling for the other variables in the model. Depending on the topic, the UK varied from, negative to positive and from significantly to insignificantly different from The Netherlands. The use of a different base country while altering the coefficients for each country's fixed effects, does not alter the sign or significances of the other results presented in Table 4. 